\title{
Intra-Industry Trade Expansion and Employment Reallocation between Sectors and Occupations
}

\author{
Manuel Cabral and Joana Silva \\ School of Economics and Management, University of Minho; \\ School of Economics and GEP, University of Nottingham
}

\begin{abstract}
This paper re-examines the relationship between trade and labour market adjustment costs by explicitly considering the effects of occupational mobility. We investigate the hypothesis that intra-industry trade expansion entails lower adjustment costs than inter-industry trade expansion-the so-called Smooth Adjustment Hypothesis (SAH). This paper makes two new contributions. First, the introduction of a new adjustment variable that considers reallocation between sectors and occupations. Second, a test of the SAH using panel data with relevant trade and non-trade control variables, which overcomes some of the methodological limitations of former studies. The results suggest a confirmation of the SAH and stress the importance of considering the effects of worker moves between occupations in the study of trade-induced adjustment. JEL no. F12, F16, J62 Keywords: Intra-industry trade; worker mobility; labour market adjustment
\end{abstract}

\section{Introduction}

In recent decades the reduction of trade barriers has been accompanied by an ongoing increase in concerns about the political, social and economic impact of trade liberalization. Particular attention has been paid to the short run costs associated with the transition between the pre- and the

Remark: We are grateful to participants at the Spring 2005 Midwest International Economics Meetings, the 4th Annual Conference of the European Economics and Finance Society and seminars at the University of Nottingham. We would specially like to thank David Greenaway, Rod Falvey, Peter Wright, Richard Upward, Maria Paula Fontoura and Nuno Sousa for very helpful comments on earlier versions of this paper. We are grateful to the Ministry of Employment, Statistics Department, for access to data used in this article. Joana Silva gratefully acknowledges financial support from Fundação para a Ciência e a Tecnologia (Grant No. SFRH/BD/13162/2003). The usual disclaimer applies. Please address correspondence to Joana Silva, Office B52, School of Economics, University of Nottingham, Nottingham, NG7 2RD; e-mail: lexjcgs@gwmail.nottingham.ac.uk 
post-liberalization equilibrium. In this context, the claim, first made by Balassa (1966) and further developed by Greenaway and Milner (1986) and Brülhart and Elliott (2002), that intra-industry trade expansion entails lower adjustment costs than inter-industry trade expansion-the Smooth Adjustment Hypothesis (SAH) — is important.

The discussion of the impact of trade on labour markets motivated a large number of recent studies that followed the development of the Marginal Intra-Industry Trade (MIIT) indexes suggested by Brülhart (1994). ${ }^{1} \mathrm{Al}-$ though some evidence in support of the SAH was recently found, the results of these studies were not fully conclusive. Here we argue that this may result from both inappropriate estimation methods and adjustment cost measures.

To test the SAH one needs to confront dynamic trade variables with a dependent variable that reflects adjustment costs in a complete and unbiased way. Most previous studies used simple correlation analysis and crude measures of adjustment costs. ${ }^{2}$ Rather than confronting the validity of the $\mathrm{SAH}$, these focused on discussing which trade variables were better suited to capture the possibility that adjustment costs are lower with intra-industry trade (IIT). Here we focus instead on improving the adjustment variable. We argue that trade expansion may imply not only a variation in total industry labour demand, but also in the composition of labour demand of each industry. Recent empirical studies of the labour market suggest that this composition effect may entail important adjustment costs.

In this paper we propose a new measure of labour market adjustment costs capable of assessing both effects. Our adjustment variable is based on occupational changes in each industry, measuring not only total changes in the employment level but also changes in the composition of the labour force of each industry. Therefore, it measures in a more complete way the total (adjustment costs) effect of trade expansion. By focusing on measuring labour reallocation in a more appropriate way, we follow Brülhart et al. (2006) and Elliott and Lindley (2006). Both introduced important improvements in the adjustment variables by considering labour movements between industries, using data on individual workers. Brülhart et al.

${ }^{1}$ Brülhart and Elliot (1998), Sarris et al. (1999), Tharakan and Calfat (1999), Porto and Costa (1999), Rossini and Burattoni (1999), Smeets and Reker (1999), Kol and Kuijpers (1999), Brülhart (2000), Brülhart and Elliott (2002).

2 The adjustment variables used in most of the studies measure only variations in total labour of a sector, a very limited adjustment variable that should not be expected to have any significant relation with the trade variables used to test the SAH. 
(2006) also consider a separate variable for movements of workers between occupations.

The new variable we introduce considers both types of trade-induced labour reallocation that plausibly correlate with adjustment costs and eliminates movements of individual workers not expected to be associated with changes in labour demand induced by trade. Our variable also allows us to consider the effects of labour reallocation between sectors as well as occupations, giving a more complete picture of adjustment. Our labour reallocation measure is used as the dependent variable in a regression model that considers trade and non-trade control variables, using Portuguese data. Our empirical work exploits a rich data set that covers approximately 2 million workers a year and more than 200,000 firms-all wage earners in the private sector. The econometric results strongly support the SAH. Given the shortage of studies that use relevant adjustment variables or regression models capable of testing the relationship between marginal intra-industry trade and adjustment predicted by the $\mathrm{SAH}$ in an appropriate way, this is an important finding.

The rest of the paper is organized as follows. Section 2 presents a review of the relevant theoretical and empirical literature on the importance of considering both reallocation between industries and occupations to measure trade-induced adjustment costs. Section 3 presents a critical overview of the adjustment variables used in previous studies. Section 4 presents our adjustment variable. Section 5 provides a description of the data set used to calculate the new variable and some descriptive evidence on its advantages. Section 6 outlines the econometric model, presents the key results of our empirical study and robustness checks. Section 7 concludes.

\section{Related Literature}

The adjustment implications of trade expansion depend on the theoretical model and type of trade expansion considered. The neo-classical model predicts that expansion will be of an inter-industry type implying that trade affects relative factor demand and factor rewards, and induces reallocation across industries. The monopolistic competition intra-industry trade literature (Helpman 1981 and Helpman and Krugman 1985) considers that matched trade has none of these implications, since the horizontally differentiated varieties of each industry have similar factor requirements. Thus, these models predict that IIT expansion does not affect the relative 
factor demand implying only limited factor reallocation within each industry. Contrary to the monopolistic competition theory, vertical IIT models assume that matched trade includes exchange of varieties produced with different factor requirements, either because high quality varieties are more capital intensive (e.g. Falvey 1981 and Falvey and Kierzkowski 1987), or because these require a higher proportion of skilled labour (Gabszewicz and Turrini 2000).

Empirical studies show that matched trade flows of varieties with different levels of quality are the dominant type of IIT (e.g. Greenaway et al. 1994 and 1995), and also that vertical IIT includes important net exchanges of factor services (Cabral et al. 2006), suggesting that matched trade expansion may affect relative factor demand and, moreover, relative demand for services of different occupational groups.

Thus, an important part of trade-induced adjustment costs may result from intra-industry trade expansion and the consequent changes in occupational requirements within each sector. This is in accordance with the theoretical work of Lovely and Nelson (2000) that argues that IIT expansion can be associated with labour reallocation. It is also consistent with evidence collected by Davis et al. (1996), that job reallocation occurs mostly within industries, and the findings of Greenaway et al. (2002) that within industries there is a high incidence of firm as well as occupational adjustment. The labour economics literature (e.g. Kletzer 1998 and Haynes et al. 2002) also emphasizes the importance of considering worker moves between occupations, suggesting that labour reallocation costs arise essentially because of occupational, not sectoral change.

\section{Adjustment Variables Used to Test the SAH}

Contributions for the measurement of adjustment costs have occurred mainly in the context of the SAH. This hypothesis that matched trade expansion leads to lower adjustment costs than net trade expansion is almost as old as the intra-industry trade literature itself (e.g. Balassa 1966; Krugman 1981). It soon became an assumption, ${ }^{3}$ which managed to survive a long time without being exposed to empirical analysis.

3 Taking "as axiomatic that IIT is associated with lower adjustment costs than net trade" (Lovely and Nelson 2000: 179), several authors argued that economic integration would be smoother between countries with similar level of development, since in these countries 
The development of dynamic intra-industry trade measures, particularly the MIIT index, suggested by Brülhart (1994), motivated numerous studies about intra-industry trade adjustment costs. Early studies analysed correlations between adjustment costs and different intra-industry trade variables. The first studies that used econometric methods suited to test the SAH include Brülhart and Elliott (1998), Sarris et al. (1999) and Tharakan and Calfat (1999). Most former studies used as a labour market adjustment costs variable either the change in total industry-level employment $\left(\Delta L_{j}\right)$ or the share of intra-industry job turnover in an industry's total job turnover $\left(\right.$ WHITHIN $\left._{j}\right)($ Table 1).

\subsection{Change in Total Industry Employment}

Industry level employment changes $\left(\Delta L_{j}\right)$ have been seen as an inverse proxy for adjustment costs. The higher/lower this variable the lower/higher the adjustment costs, based on the assumption that the lower the employment loss implied by trade the lower the adjustment costs. As Brülhart and Elliott (1998) argue, net sector employment change is a measure of net employment performance rather than adjustment costs.

Measures of employment performance should not necessarily be expected to be systematically related to type of trade expansion. In this case, no clear relation can be predicted between $M I I T_{j}$ and $\Delta L_{j}$. As Greenaway and Milner (1986: 80) have pointed out, "the exchange of differentiated products (IIT) by a country with the rest of the world can change without any change in its production structure and therefore without affecting specialization". Consequently, matched trade expansion may not affect the total production of each sector leaving the respective size of the labour force unaltered. Therefore, higher levels of MIIT are expected to be associated with lower levels of variation in total employment of each sector, while in industries where the inter-industry component of trade expansion is dominant (industries with lower MIIT indexes) the net change in total employment can be either positive (in industries with net export expansion) or negative (in industries with net import expansion) and so either larger or smaller than in industries where the intra-industry component of trade expansion is dominant.

intra-industry trade flows tend to dominate trade (e.g. Krugman 1987; Greenaway and Hine 1991). 
Table 1: Adjustment Costs Variables Considered in Former SAH Studies

\begin{tabular}{|c|c|c|}
\hline Variable & Definition & Studies \\
\hline$\Delta L_{j}$ & $\begin{array}{l}\frac{L_{j}^{1}-L_{j}^{0}}{\left(L_{j}^{1}+L_{j}^{0}\right) \times 0,5} \times 100, \\
\text { where } L_{j}^{1} \text { and } L_{j}^{0} \text { are, respectively, the number } \\
\text { of workers in sector } j \text { in the initial }(0) \text { and final } \\
\text { (1) year of the period under analysis. }\end{array}$ & $\begin{array}{l}\text { Hine et al. (1994) } \\
\text { Porto and Costa (1999) }{ }^{\mathrm{a}} \\
\text { Rossini and Burattoni }(1999)^{\mathrm{a}} \\
\text { Kol and Kuijpers }(1999)^{\mathrm{a}} \\
\text { Smeets and Reker }(1999)^{\mathrm{a}} \\
\text { Brülhart and Elliott (1998) } \\
\text { Sarris et al. (1999) } \\
\text { Tharakan and Calfat (1999) }\end{array}$ \\
\hline \multirow[t]{2}{*}{$W_{T T H I N}^{n}$} & $\frac{\left(P O S_{j}+N E G_{j}\right)-\left|P O S_{j}-N E G_{j}\right|}{P O S \cdot+N F G}$ with & $\begin{array}{l}\text { Brülhart et al. }(2004)^{c} \\
\text { Brülhart }(2000)^{c}\end{array}$ \\
\hline & $\begin{array}{l}P O S_{j}=\sum_{i}\left(L_{i}^{1}-L_{i}^{0}\right) \text { if } L_{i}^{1}-L_{i}^{0}>0 \\
N E G_{j}=\sum_{i}\left|L_{i}^{1}-L_{i}^{0}\right| \text { if } L_{i}^{1}-L_{i}^{0}<0 \\
\text { where } i \text { stands for firm and } j \text { stands for indus- } \\
\text { try. }\end{array}$ & \\
\hline DURATION $_{j}$ & $\begin{array}{l}\text { Average duration of the period of unemploy- } \\
\text { ment of the unemployed workers dismissed } \\
\text { from the industry } j \text {. }\end{array}$ & Brülhart and Elliott $(2002)^{b}$ \\
\hline$W A G E V A R_{j}$ & $\begin{array}{l}\text { Standard deviation of the real wage of the in- } \\
\text { dustry. }\end{array}$ & Brülhart and Elliott $(2002)^{b}$ \\
\hline CWAGEVAR & $\begin{array}{l}\text { Standard deviation of the real wage of the in- } \\
\text { dustry calculated via the estimated coefficients } \\
\text { of the sectoral Phillips curve. }\end{array}$ & Brülhart and Elliott $(2002)^{b}$ \\
\hline $\begin{array}{l}\text { INTRA- and } \\
\text { INTER IND } \\
\text { MOVER }\end{array}$ & $\begin{array}{l}\text { Registers the change in firm or industry of em- } \\
\text { ployment for each individual. Does not con- } \\
\text { sider changes in occupations. }\end{array}$ & Elliott and Lindley $(2006)^{c}$ \\
\hline$I N D M O V E_{j}$ & $\begin{array}{l}\frac{\sum_{x} m_{x j}}{L_{j}}=\text { share of industry moves } \\
\text { with } m_{x j}=1 \text { if the worker } x \text { of industry } j \\
\text { moved to a different industry, and } m=0 \text { if the } \\
\text { worker stayed. }\end{array}$ & Brülhart et al. $(2006)^{c}$ \\
\hline OCCMOVE & $\begin{array}{l}\frac{\sum_{x} z_{x j}}{L_{j}}=\text { share of occupation moves } \\
\text { with } z=1 \text { if the worker } x \text { of industry } j \text { moved } \\
\text { to a different occupation, and } z=0 \text { if the } \\
\text { worker remained the same occupation. }\end{array}$ & Brülhart et al. $(2006)^{\mathrm{c}}$ \\
\hline
\end{tabular}

\footnotetext{
a Studies that use only simple correlations. ${ }^{\text {b }}$ Studies where an equation was estimated using cross
} section single equation models. ${ }^{\mathrm{c}}$ Studies where an equation was estimated employing panel models. 
To overcome this problem Brülhart (1999) suggests the use of an alternative measure-the absolute value of total employment changes $\left(\left|\Delta L_{j}\right|\right)$. According to the SAH the relation between this and MIIT should be negative. This variable, although more appropriate, still has two problems, that it shares with the previous one $\left(\Delta L_{j}\right)$. First, it is limited because it is based on a restrictive interpretation of reallocation adjustment costs. For example, in an industry where 10,000 operatives are dismissed and 10,000 managers or engineers employed, this variable would register no adjustment costs. This vision of adjustment costs abstracts from the microeconomic costs (faced by individuals) of dismissal. Recent work in the labour literature (e.g. Kletzer 1998 and Haynes et al. 2002) emphasize the importance of these costs suggesting that changing occupation can be the major cause of adjustment costs.

Second, it is biased towards confirmation of the hypothesis, since it counts only variations in total employment, ignoring the effects of changes in the composition of each industry's labour force that may result from openness to trade. One may admit that net trade expansion will affect (either positively or negatively) total production of the sector, and consequently total employment. By contrast, matched trade expansion will tend to have smaller effects on total demand and total employment in each sector, but may affect the composition of the labour requirements of each sector. In particular, we would expect this to happen in the case of exchanges of vertically differentiated products of the same industry. In this case intraindustry trade may induce important adjustments in the labour markets that would be missed by the variable $\left(\left|\Delta L_{j}\right|\right)$.

\subsection{Job Turnover}

A different variable used is based on job turnover: WITHIN. Brülhart et al. (2004) and Brülhart (2000) used this variable, initially proposed by Davis and Haltiwanger (1992), in the context of the SAH. It reflects the importance of labour reallocation within an industry. This variable is based on the idea, confirmed by Davis et al. (1996), that the degree of job reallocation is well beyond net aggregate employment creation and destruction and job flows across sectors.

Job turnover may be higher in sector A than in sector B for at least two different reasons. One is when the sector is firing one type of worker (say operatives) and hiring another type (e.g. engineers). In this case one would expect higher adjustment costs. Another reason that may explain higher job 
turnover in one sector is that intra-sectoral job reallocation is easier. But the reasons for this tend to be linked to sector specificities ${ }^{4}$ which should not be expected to be influenced by the share of matched trade flows in trade expansion.

Empirical studies using variables based on job turnover assume that these reflect lower adjustment costs. The argument is that changing jobs within the same sector implies less adjustment than changing between sectors, so sectors with a large WITHIN will have less adjustment. We accept the first part of the argument as reasonable, but question the link with the second. First, not changing firm may have even less adjustment costs than changing between firms in the same sector. Second, a large number of people being accepted and fired in the same sector does not mean that it is the same people moving within the sector. It could be a result of people with lower qualifications leaving the sector while more qualified workers are being employed. In this case, bigger WITHIN would reflect bigger adjustment costs, just the opposite of the argument assumed. Furthermore, Haynes et al. (2002) collected evidence that supports the idea that labour transfers between sectors maintaining the same occupation/job do not imply higher adjustment costs than labour transfers within the same sector involving occupation/job change.

Alternative adjustment variables based on wage variations and unemployment duration by sector (WAGEVAR $R_{j}$ and $C W A G E V A R_{j}$ and $D U R-$ $A T I O N_{j}$ in Table 1) were introduced by Brülhart and Elliott (2002). However, by contrast to labour reallocation, these are not indicators of trade-induced adjustment effects and therefore of sectoral incidence of adjustment costs, but of the degree of sector-level constraints to factor reallocation and wage rigidity. ${ }^{5}$

${ }^{4}$ For example, sectors where the skills are more firm specific may have less job turnover than sectors where these are sector specific. The role of institutional factors, such as union membership, and type of contracts, may also influence job turnover, as well as the characteristics of the labour requirements of the sector. These may be influenced by exposure to trade, but the theory does not predict that the share of matched trade flows in trade expansion has an unambiguous effect.

5 These variables reflect sectoral characteristics of labour markets such as geographical concentration, specificity of labour skills of the industry, market power and unionization. To test the SAH using these variables it is necessary to assume that wage flexibility and/or labour mobility are higher at intra-industry level, and to identify intra-industry trade expansion with intra-industrial reallocation and inter-industry trade expansion with interindustrial reallocation, which is not rigorous (for more detailed discussion see Greenaway and Milner 1986 and Greenaway et al. 2002). 


\subsection{Individual-Level Data}

Recent studies of Brülhart et al. (2006) and Elliott and Lindley (2006) also focus on improving the measurement of adjustment costs. These authors study the relationship between intra-industry trade and labour reallocation using individual-level data on manufacturing worker moves in the United Kingdom. Brülhart et al. (2006) estimate the impact of different types of trade flows on worker moves both between industries and occupations. This is a very important contribution since worker moves between occupations were ignored in former SAH studies. Brülhart et al. (2006: 521) conclude that "intra-industry trade does have the stipulated attenuating effect on worker moves, both between occupations and between industries". They use two types of dependent variables, one for worker moves between industries and another for worker moves between occupations. Here we follow the same line. In addition however, we construct an industry level variable that allows us to aggregate occupation and sector moves into one adjustment variable. It therefore provides a measure of total adjustment costs that one can relate to marginal IIT variables.

Brülhart et al. (2006) and Elliott and Lindley (2006) consider individual observations for each worker included in the UK's Quarterly Labour Force Survey in two different years. The use of individual worker data has the advantage of increasing the number of observations. But it also means that a large number of worker moves may be motivated by individual reasons rather than industry adjustment to trade expansion. Brülhart et al. (2006: 541) note that an important limitation is that they are unable to "distinguish between voluntary and involuntary moves". Another limitation of using individual level data is that one cannot distinguish moves motivated by changes in the sector from those that result from individual reasons. While the first group of reasons should be expected to be related to trade expansion $^{6}$ and to involuntary moves, the second includes worker movements that should not be expected to be related to trade changes, but rather to individual worker and job characteristics, ${ }^{7}$ which include both voluntary and involuntary moves. The inclusion of both types of moves might be one of the reasons why Brülhart et al. (2006: 521) conclude that the effect of trade variables is "relatively small compared to other determinants of labour

\footnotetext{
6 Trade expansion, as well as changes in demand and in technology, might affect the relative size and occupational requirements of the different sectors.

7 Such as willingness to take risks, level of qualifications, career prospects offered by the job or firm size.
} 
reallocation", ${ }^{8}$ such as age, working in a large firm, working part time, being married or a home owner.

Our variable, although considering both movements between occupations and industries, considers only movements of workers that are related to changes in the size of the labour force of each sector or to relative occupational requirements of each sector, thereby excluding worker moves motivated only by individual reasons, the inclusion of which may create a problem of omitted variable bias ${ }^{9}$ and overstate the adjustment costs resulting from trade expansion. ${ }^{10}$

\section{A New Adjustment Costs Variable}

The total (reallocation) effect $\left(T E_{j}\right)$ is equal to the sum of the net variations of workers in each occupational group (in absolute value) weighted by average total employment of the industry in the period. ${ }^{11}$ This effect is measured by

$$
\begin{aligned}
T E_{j} & =D E_{j}+C E_{j} \\
& =\frac{\left|L_{j}^{1}-L_{j}^{0}\right|}{\left(L_{j}^{0}+L_{j}^{1}\right) \times 0,5}+\frac{\left(\sum_{k}\left|L_{j k}^{1}-L_{j k}^{0}\right|\right)-\left|L_{j}^{1}-L_{j}^{0}\right|}{\left(L_{j}^{0}+L_{j}^{1}\right) \times 0,5} \\
& =\frac{\sum_{k}\left|L_{j k}^{1}-L_{j k}^{0}\right|}{\left(L_{j}^{0}+L_{j}^{1}\right) \times 0,5},
\end{aligned}
$$

8 Brülhart et al. (2004) also note that the low degree of import penetration of the United Kingdom may also explain the low relative importance of the effect of trade variables. This might differ for the Portuguese case since the weight of import penetration in the Portuguese national income is twice that of the United Kingdom.

9 If we consider that the proxy control variables only capture a part of the individual workers motivations.

10 If 100 plant operators are replaced by 100 plant operators in sector A, because the first voluntarily moved industry or because their performance was unsatisfactory, and if in sector B 100 plant operators are dismissed without replacement, the measures of adjustment suggested by Brülhart et al. (2004) imply that adjustment costs in the first case were twice those of the second. However, factor reallocation that occurred in the first case cannot be plausibly correlated with the pattern of change in trade flows (no job extinction was involved). In this sense this variable may overestimate the labour market adjustment costs associated with trade expansion of some sectors.

11 Dividing for average total employment of the industry in the period corresponds to scaling for the dimension of each industry. In the context of the SAH this methodological 
where $L_{j k}^{0}$ and $L_{j k}^{1}$ are, respectively, the number of workers in the industry $j$ that belong to the professional group $k$ in the initial (0) and final (1) year of the period under analysis.

This variable combines the variation in total labour demand of the industry - the variation of the industry's employment level—Dimension Effect $\left(D E_{j}\right)$ - with the variation in the relative demand of different occupational groups that do not affect the demand for labour in the industryComposition Effect $\left(C E_{j}\right)$. This is zero when the number of workers in each professional group and industry does not change during the period. The higher the value assumed by $T E_{j}$, the higher the employment reallocation and thus the higher the adjustment costs.

This adjustment variable has several advantages for SAH investigation:

- It is more informative than the alternatives: Most previous work did not account for the adjustment effects of changes in the occupational structure of employment in each industry. Ignoring this may underestimate adjustment costs and potentially rank sectors according to adjustment in an inappropriate way.

- It is unbiased: Another advantage of this variable for the test of the SAH is that it is not biased in relation to the type of trade flow. Variables like $\left(\Delta L_{j}\right)$ or $\left(\left|\Delta L_{j}\right|\right)$ will tend to measure mainly the type of adjustments that one expects from unmatched trade expansion. Our new measure also considers changes in the occupational composition that might be expected to result both from matched and unmatched trade expansion.

- It is theory consistent: We measure changes in the size and composition of the labour force of each industry that can easily be related to trade changes. Although other factors, such as changes in apparent demand or technology may also affect labour demand, trade changes will influence reallocation in the predicted way. The variable is also more in line with those considered in labour economics studies of individual worker adjustment costs (see e.g. Jacobson et al. 1993; Shin 1997; Kletzer 1998). It is also in accordance with recent work of Greenaway et al. (2000) and Haynes et al. (2002) that suggest that occupational changes are the main cause of adjustment costs, and with studies about adjustment in transition economies that show that transition involved massive occupational changes (Campos

option is necessary because the same volume of changes in the number of employees induced by trade expansion in industries with different dimension implies adjustment costs of different magnitude. 
and Dabusinskas 2002) and that adjustment costs are strongly associated with qualifications (Brown and Earle 2003).

- It allows gathering occupational and sectoral reallocation and requires less information: The variable presented here allows us to aggregate the two reallocation movements (occupational and sectoral), which seems a more appropriate method for testing the SAH than separating the two. In addition, by excluding worker moves that do not result from changes in the relative requirements of each sector, it is more focused on measuring the reallocation costs imposed by trade expansion than the approach based on individual worker moves - being less exposed to omitted variable estimation problems. It also has the advantage of requiring data only at the industry-level.

\section{Labour Adjustment: Data Base and Descriptive Evidence}

To calculate the adjustment variable, we use a large matched employeremployee annual data set Quadros de Pessoal collected by the Portuguese Ministry of Employment. This covers all firms with wage earners located in Portugal, around 200,000 firms and more than 2 million workers in each year, providing comprehensive information about the industry and occupational status of each worker. We use data of manufacturing firms for the years 1995, 1997 and 1999 (a total of 832,156 workers per year), calculating the adjustment variable using 1-digit occupational groups ${ }^{12}$ for 98 industries defined at the 3-digit level of NACE-Rev. 2.

Tables 2 and 3 report summary information on the average total, dimension and composition effects for the two periods considered. It shows that measuring reallocation considering only the dimension effect seriously underestimates adjustment costs. In both periods, on average more than 30 per cent of the total changes in each sector (TE) consisted of changes of the relative weight of the different occupational groups that did not affect total employment of the industry (CE). Furthermore, the composition effect in high MIIT industries appears to be the dominant cause of adjustment

12 The professional groups were classified according to the national classification of occupations (CNP) that includes 8 groups: Managers and Administrators; Professional occupations, scientists and teachers (Specialists); Technicians and professionals of intermediate level; Clerical, Secretarial occupations; Sales occupations; Plant operatives; Machine operators; Others. 
Table 2: Summary Information on Adjustment, 1995-1997 and 1997-1999

\begin{tabular}{ccccc}
\hline & $\begin{array}{c}\text { Total } \\
\text { effect } \\
(\mathrm{TE})\end{array}$ & $\begin{array}{c}\text { Dimension } \\
\text { effect } \\
(\mathrm{DE})\end{array}$ & $\begin{array}{c}\text { Composition } \\
\text { effect } \\
(\mathrm{CE})\end{array}$ & $\begin{array}{c}\text { Share of industries } \\
\text { where CE is } \\
\text { dominant }\end{array}$ \\
\hline $1995-1997$ & 0,300 & 0,184 & 0,116 & $43,9 \%$ \\
$1997-1999$ & 0,237 & 0,164 & 0,073 & $38,8 \%$ \\
\hline
\end{tabular}

Table 3: Comparison of Average Adjustment in High and Low MIIT Industries

\begin{tabular}{lccccc}
\hline & \multicolumn{2}{c}{ Industries with low MIIT } & & \multicolumn{2}{c}{ Industries with high MIIT } \\
\cline { 2 - 3 } \cline { 5 - 6 } Type of Effect & $1995-1997$ & $1997-1999$ & & $1995-1997$ & $1997-1999$ \\
\hline \multirow{2}{*}{ TE } & 0,337 & 0,26 & & 0,218 & 0,182 \\
DE & 0,221 & 0,179 & & 0,103 & 0,060 \\
& $(65,5 \%)$ & $(69,1 \%)$ & & $(47,2 \%)$ & $(30,4 \%)$ \\
CE & 0,117 & 0,08 & & 0,115 & 0,127 \\
& $(34,5 \%)$ & $(30,9 \%)$ & & $(52,8 \%)$ & $(69,6 \%)$ \\
\hline
\end{tabular}

Note: High MIIT industries are defined as those with an MIIT index above 50\%; the values in parentheses show the proportion of each effect on the total effect.

costs while in low MIIT industries the adjustment costs are mainly due to the dimensional effect.

Our measure of the total reallocation effect (TE), on average, is higher in low than in high MIIT industries. However, this evidence is not sufficient to conclude that the SAH is valid. Industries differ in trade flows but also in other characteristics that affect the level of labour adjustment costs, which should be controlled for.

\section{Empirical Model and Results}

We apply our new measure to the test of the SAH. We constructed an industry-level sample for the periods 1995-1997 and 1997-1999 and, then, a balanced panel of total effect, trade and other potentially relevant variables for Portuguese manufacturing sectors using three sources of information: Industry-level employment data by occupation and by qualification of Quadros de Pessoal, "Firm Statistics - Manufacturing Industry" collected by the Portuguese Statistical Office, and the data set on international trade 
BDCI collected by the Portuguese Office of Studies and Economic Prospective (GEPE). The panel used for estimation consists of observations on 98 industries over two periods: 1995-1997 and 1997-1999.

\subsection{Empirical Model}

Neither trade nor labour theory equip us with a fully specified model of labour market adjustment nor provide firm priors on which control variables should be included in a model testing the SAH. However, past empirical and theoretical work gives useful guidance.

To measure the nature of trade expansion we use the marginal intraindustry index proposed by Brülhart (1994). This is the dynamic index used in most of the SAH literature. Differently from the GL index and its change, it assesses the proportion of marginal trade that is intra-industry type. ${ }^{13}$ Following Brülhart and Elliott (2002) we include two trade control variables: exposure to trade and an interaction term between this variable and MIIT. The latter allows us to test the additional hypothesis, that the more open an industry is, the more the structure of change in trade flows affects the adjustment costs in the way predicted by the SAH. However, we also control for non-trade influences. Changes in labour allocation may reflect changes in domestic demand as well as in external demand. Therefore, we include the change in apparent demand, which controls for sector-specific shocks. We also use skilled labour intensity of each industry as a control variable. This is expected to have a positive sign. It was used in empirical studies (see, e.g. Brülhart et al. 2004) as a proxy for technology-intensity, which is argued to be positively associated with employment adjustment. On the other hand, labour market studies also suggest that skilled workers tend to move more between industries and occupations. ${ }^{14}$ Thus we expect more skill intensive industries to be associated with higher number of worker moves.

Based on these priors we constructed and estimated model (1) - estimated trough pooled OLS — and model (2) —estimated using fixed effects:

$$
\begin{aligned}
\ln T E_{j}= & \theta_{1}+\theta_{2} M_{I I T} T_{j}+\theta_{3} O T_{j}+\theta_{4} O T_{-} M I I T_{j} \\
& +\theta_{5} \Delta A D_{j}+\theta_{5} S_{j}+\theta_{6} D 9799+v_{j},
\end{aligned}
$$

\footnotetext{
13 For discussion of the properties different IIT indexes see Oliveras and Terra (1997) and Brülhart (2002).

14 See, e.g. Shin 1997; Jacobson et al. 1993; Greenaway et al. 1999, 2002; Haynes et al. 2002.
} 


$$
\begin{aligned}
\ln T E_{j t}= & \lambda_{1}+\lambda_{2} \text { MIIT }_{j t}+\lambda_{3} O T_{j t}+\lambda_{4} O T_{-} M I I T_{j t} \\
& +\lambda_{5} \Delta A D_{j t}+\lambda_{5} S_{j t}+\lambda_{6} D 9799_{t}+z_{j t} .
\end{aligned}
$$

The $j$ subscripts identify the industry and $t$ subscripts identify the period (1995-1997 or 1997-1999). The dependent variable $\ln T E_{j t}$ is the log of the total effect in industry $j$ in period $t, M I I T$ is the log of Brülhart's (1994) MIIT index $\left(A_{j t}\right),{ }^{15} \mathrm{OT}$ is the degree of trade exposure, OT_MIIT is the interaction between openness and marginal intra-industry trade, $\triangle A D$ is the change in apparent demand; $S$ is the proportion of skilled workers in each sector; and D9799 is a dummy variable taking the value 1 in the period 1997-1999 (and 0 otherwise). $v_{j}$ and $z_{j t}$ are disturbance terms. Definitions and methods of construction of these variables are given in the Appendix Table A1. Summary statistics and the correlation matrix are shown in Tables A2 and A3.

We expect the following signs for the coefficients of the variables: MIIT $<0, O T>0, O T \_M I T<0, \triangle \mathrm{AD}<0$ and $S \gtrless 0$. According to the SAH, the higher the proportion of marginal trade which is intra-industry the lower are total adjustment costs. The sign on the openness coefficient is expected to be positive because higher exposure to trade means stronger competitive pressures, therefore higher necessity of firms and industries to adapt more frequently to changing competitive positions (see Brülhart 2000). As a result, an increase in trade openness is expected to be associated with higher employment adjustment and therefore adjustment costs. According to our additional hypothesis the coefficient associated with the interaction term is expected to be negative. Moreover, total employment adjustment will be more severe in declining than in expanding sectors. Finally, as suggested earlier, we do not have strong priors on the sign of the relationship between the proportion of skilled workers in each sector and adjustment costs.

\subsection{Results}

Table 4 reports pooled OLS estimates for model (1) and the fixed-effects estimates for model (2) with and without control variables.

\footnotetext{
15 Theory does not suggest a functional form of the relation between adjustment costs and MIIT. Therefore, we decided to regress, using panel fixed effects, $\ln T E_{j t}$ against a constant term and two explained variables: $A_{j t}$ and $\ln A_{j t}$, where $A_{j t}$ is the MIIT index (see Table A1). As the only statically significant coefficient was the one associated with $\ln A_{j t}$ we decide to use log-log specification. Moreover, we also estimated all the models using $A_{j t}$ instead of $\ln A_{j t}$ and the results were very similar apart from the ones on the RESET test that were less robust.
} 
Table 4: Adjustment Costs and Marginal Intra-Industry Trade: Estimated Results

\begin{tabular}{lllll}
\hline & \multicolumn{4}{c}{ Dependent variable $=$ ln TE } \\
& \multicolumn{3}{c}{ Pooled OLS } & \multicolumn{2}{c}{ Fixed effects } \\
\hline Constant & -1.837 & -2.369 & -2.17 & -2.599 \\
& $(19.95)^{\mathrm{a} * * *}$ & $(17.53)^{* * *}$ & $(6.72)^{* * *}$ & $(5.11)^{* * *}$ \\
MIIT & -0.086 & -0.108 & -0.21 & -0.286 \\
& $(3.85)^{\mathrm{a} * * *}$ & $(4.48)^{* * *}$ & $(-1.76)^{*}$ & $(2.75)^{* * *}$ \\
OT & - & 0.074 & - & 0.05 \\
& & $(3.82)^{* * *}$ & & $(1.08)$ \\
OT_MIIT & - & 0.006 & - & 0.017 \\
& & $(1.84)^{*}$ & & $(2.15)^{* *}$ \\
$\Delta$ AD & - & -0.379 & - & -0.45 \\
& & $(3.49)^{* * *}$ & & $(4.69)^{* * *}$ \\
$S$ & - & 1.49 & - & 1.372 \\
& & $(3.73)^{* * *}$ & & $(0.76)$ \\
D9799 & $-0.147^{\mathrm{a}}$ & -0.219 & -0.16 & -0.182 \\
& $(1.33)$ & $(2.18)^{* *}$ & $(2.39)^{* *}$ & $(2.73)^{* * *}$ \\
$R^{2}$ & 0.09 & 0.28 & 0.031 & 0.31 \\
F-statistic & $8.47^{* * *}$ & $12.23^{* * *}$ & $3.08^{*}$ & $8.32^{* * *}$ \\
No. of industries & 98 & 98 & 98 & 98 \\
No. of observations & 196 & 196 & 196 & 196 \\
Adjusted $R^{2}$ & 0.0799 & 0.257 & 0.021 & 0.270 \\
RESET-test (F-stat. $)$ & 1.41 & 0.6 & 0.72 & 0.37 \\
White-test $\left(\chi^{2}\right)$ & $9.50^{* *}$ & 21.02 & 0.78 & 11.43 \\
& $\mathrm{a}$ & - & - & - \\
\hline
\end{tabular}

***,**,* denote significantly difference from 0 at the 1,5 and 10 per cent level respectively. The figures in parentheses are absolute values of $t$-ratios.

${ }^{\text {a }}$ Robust t-ratio.

The general performance of the models is satisfactory. The F-test on the joint significance of the regressors is strongly statistically significant. There is no evidence of misspecification, since the RESET-test statistic is never statistically significant.

The results support the hypothesis that intra-industry trade expansion entails lower adjustment costs than trade expansion of an inter-industry type. Moreover, this result is robust to the inclusion of other trade and nontrade characteristics of industries even non-observed ones. The estimated coefficient on MIIT is negative and statistically significant, as predicted by the SAH. Other things being equal, a 10 per cent higher MIIT implies a 2.1 per cent smaller total (employment adjustment) effect. ${ }^{16}$

\footnotetext{
16 The marginal effect depends on openness to trade: $\partial E T / \partial M I T T=\lambda_{2}+\lambda_{4} O T$. We use the average OT and calculate the marginal effect as $-0.213(=-0.286+0.017 O \bar{T})$.
} 
In addition, all signs of the coefficients of the control variables are the same in pooled OLS and fixed-effects estimation. The coefficient associated with changes in apparent demand has the expected sign and the variable is statistically significant in all models. The openness to trade coefficient also has the expected sign but its significance does not hold when industry fixed effects are included. We also investigated the existence of interactions between openness to trade and marginal intra-industry trade (MIIT), and in particular the hypothesis of whether trade exposure raises the negative impact of MIIT on adjustment costs. Although the correlation analysis suggested this, regression analysis does not support this hypothesis.

\subsection{Robustness}

Table A4 reports a number of robustness checks of our findings. First, we report estimates using different specifications, with similar results. In all the cases, the MIIT variable has a negative sign and is statistically significant. Second, the next two columns show robustness in different sub-samples of the data. This procedure was suggested by Oliveras and Terra (1997) who argue that "The overall index can take the same value due to very different adjustment processes with respect to resource allocation. These processes can be identified by the sub-indices and thus avoid an inadequate interpretation of the general process" (Oliveras and Terra 1997: 171). Results for each period show that splitting the sample period has little effect on the results both in terms of signs, statistically significant variables and relative magnitude of the estimated coefficients. This is reassuring and points to the robustness of our results.

Third, the two final columns report results using our new adjustment measure but calculated using alternate data from our same data set. Instead of using employment data classified by occupation we turn to employment data classified by qualification. The adjustment costs measure computed is

$$
\begin{aligned}
T E Q_{j} & =\frac{\left|L_{j}^{1}-L_{j}^{0}\right|}{\left(L_{j}^{0}+L_{j}^{1}\right) \times 0,5}+\frac{\left(\sum_{k}\left|L_{j q}^{1}-L_{j q}^{0}\right|\right)-\left|L_{j}^{1}-L_{j}^{0}\right|}{\left(L_{j}^{0}+L_{j}^{1}\right) \times 0,5} \\
& =\frac{\sum_{k}\left|L_{j q}^{1}-L_{j q}^{0}\right|}{\left(L_{j}^{0}+L_{j}^{1}\right) \times 0,5},
\end{aligned}
$$


where $L_{j q}^{0}$ and $L_{j q}^{1}$ are, respectively, the number of workers in the industry $j$ with the level of academic/training qualification/skill $q$ in the initial (0) and final (1) year of the period under analysis. ${ }^{17}$ Note that although there is a high correlation between this and $T E_{j}$ (correlation coefficient equal to 0.855 ) there is no full correspondence between the two measures. The results obtained are very similar to those reported in Table 4, both in terms of signs, degree of statistical significance and orders of magnitude of the estimated coefficients. This is reassuring and points to the robustness of our results to a different type of data that reflects labour reallocation between occupations.

It is worth noting that the robustness obtained by the evidence, when testing the $\mathrm{SAH}$ using the new measure of adjustment costs $\left(T E_{j}\right)$ contrasts with the weakness of the results obtained when the dependent variable is the change in total employment $\left(D E_{j}\right.$, that is used in most previous studies-see Table A5).

This means that better results are obtained when both occupational and sectoral reallocation are considered. This is important, since in this case the additional information contributes to a more rigorous test of the SAH. Moreover, it is in line with the idea that limited post-liberalization intersectoral labour movements, as those uncovered by Waczierg and Wallack (2004), can co-exist with significant intra-sectoral movements. This result is also consistent with evidence collected by Greenaway et al. (2002) that suggests that there is no systematic relationship between the type of trade expansion and the inter- or intra-industry nature of labour reallocation.

\section{Conclusions}

This paper makes two contributions to the intra-industry trade literature. First, it introduces a new measure of adjustment costs that considers the effects of reallocations between sectors and occupations in an unbiased way. This variable is more in accordance with labour theory than most of those used in former studies and requires only industry level data. Second, it presents a test of the SAH for the case of a small open economy (Portugal), using multiple regressions with control variables and fixed effects and a new adjustment variable. The evidence obtained suggests support for the SAH in Portugal.

17 The levels of qualification considered are: 1 - Administrators and top managers, 2 - Intermediate managers, 3 - Clerical, secretarial, 4 - High qualified professionals, 5 - Technical professionals, 6 - Semi-skilled workers, 7 - Unskilled workers, 8 - Trainees, 9 - Others. 
We examine the adjustment implications of different types of trade expansion, suggesting an alternative approach to test the hypothesis that intra-industry trade expansion entails lower adjustment costs than interindustry trade expansion. The recent contributions of Elliott and Lindley (2006) and Brülhart et al. (2006) illustrate the limitations of previous work, and the need to improve adjustment variables if the SAH is to be tested in a sensible way. Only the last of these papers considered the effect of movements of workers between occupations on adjustment costs. An effect that our evidence suggests is of great importance to adjustment costs, particularly in industries with high levels of MIIT.

Our adjustment variable is based on occupational changes in each industry, measuring not only the total changes in employment level but also changes in the composition of the labour force of each industry. Therefore, we believe that it measures in a more complete way the total reallocation adjustment cost effects of a trade expansion. Our new variable has a number of useful features. First, it is more informative, second it is unbiased in relation to the type of trade flow, third it is sustained in a more complete and realistic view of the adjustment implications of trade expansion, and fourth it is more theory consistent and aligned with the way adjustment costs have been measured in other types of studies in labour economics. We use this variable in an industry-level panel data model of Portuguese manufacturing, which includes trade and non-trade control variables to test the SAH and our econometric results support the SAH.

\section{Appendix}

Table A1: Variables Description

\begin{tabular}{lll}
\hline Variable & Definitions & \multicolumn{1}{c}{ Method of construction } \\
\hline $\ln T E$ & $\begin{array}{l}\text { Total (costly } \\
\text { employment } \\
\text { adjustment) } \\
\text { effect }\end{array}$ & $\ln T E_{j}=\ln \left\{\frac{\sum_{k}\left|L_{j k}^{1}-L_{j k}^{0}\right|}{\left(L_{j}^{0}+L_{j}^{1}\right) \times 0,5}\right\}$, \\
& $\begin{array}{l}\text { where } L_{j k}^{0} \text { and } L_{j k}^{1} \text { are, respectively, the number of workers in the in- } \\
\text { dustry } j \text { that belong to the professional category } k \text { on the initial }(0) \\
\text { and final }(1) \text { year of the period } t .\end{array}$ \\
MIIT & $\begin{array}{l}\text { Leg calculated } M I I T \text { for } 3 \text {-digit NACE industries based on data from } \\
\text { proportion } \\
\text { of marginal } \\
\text { trade of the } \\
\text { intra-indus- } \\
\text { try type }\end{array}$ & $\begin{array}{l}\text { 4-digit NACE industries in order to avoid the categorical aggregation } \\
\text { problem. }\end{array}$ \\
MIIT $T_{j}=\ln \left(A_{j}\right)=\ln \left\{\sum_{i=1}^{i}\left(W_{i} \times A_{i}\right)\right\}$ where
\end{tabular}


Table A1: continued

\begin{tabular}{lcc}
\hline Variable & Definitions & \multicolumn{1}{c}{ Method of construction } \\
\hline & $W_{i}=\frac{|\Delta X|_{i}+|\Delta M|_{i}}{\sum_{i=1}^{I j}\left(|\Delta X|_{i}+|\Delta M|_{i}\right)}$ and $A_{i}=1-\frac{\left|\Delta X_{i}-\Delta M_{i}\right|}{\left|\Delta X_{i}\right|+\left|\Delta M_{i}\right|}$. \\
& $\begin{array}{l}\text { We have used the } j \text { subscripts to identify 3-digit NACE-Rev. 2 industry, } \\
i \text { subscripts to identify 4-digit NACE-Rev. 2 industries. Each } j \text { industry } \\
\text { includes Ij industries } i . \Delta \text { is the difference operator. } X \text { and } M \text { denote, } \\
\text { respectively, exports and imports. }\end{array}$ \\
OT & $\begin{array}{l}\text { Average ratio } \\
\text { of total trade } \\
\text { to output } \\
\text { Change in } \\
\text { apparent } \\
\text { demand }\end{array}$ & $O T_{j}=\frac{\left[\left(X_{j}+M_{j}\right)^{1}+\left(X_{j}+M_{j}\right)^{0}\right]}{O U T P U T_{j}^{1}+O U T P U T_{j}^{0}}$ \\
\hline $\begin{array}{l}\text { Share of } \\
\text { skilled wor- } \\
\text { kers in total } \\
\text { labour force }\end{array}$ & $S_{j}=\frac{H_{j}}{L_{j}}$, where $H$ refers to skilled workers and $L$ refers to total \\
number of workers.
\end{tabular}

Table A2: Summary Statistics $(n=196)$

\begin{tabular}{lrr}
\hline & \multicolumn{1}{c}{ Mean } & Std. Dev. \\
\hline $\ln T E$ & -1.67523 & 0.80844 \\
MIIT & -2.73864 & 2.75427 \\
OT & 4.27187 & 5.15753 \\
OT_MIIT & -12.57870 & 32.85390 \\
$\triangle A D$ & 0.12869 & 0.46210 \\
$S$ & 0.21342 & 0.12770 \\
\hline
\end{tabular}

Table A3: Correlation Matrix

\begin{tabular}{lrccccc}
\hline & $\ln T E$ & MIIT & OT & OT_MIIT & $\triangle A D$ & $S$ \\
\hline $\ln T E$ & 1 & - & - & - & - & - \\
MIIT & -0.2909 & 1 & - & - & - & - \\
OT & 0.2544 & -0.0622 & 1 & - & - & - \\
OT_MIIT & -0.2446 & 0.4324 & -0.8029 & 1 & - & - \\
$\triangle A D$ & -0.1955 & -0.0091 & 0.0746 & -0.0450 & 1 & - \\
$S$ & 0.2558 & -0.0370 & -0.0499 & 0.1081 & -0.0398 & 1 \\
\hline
\end{tabular}




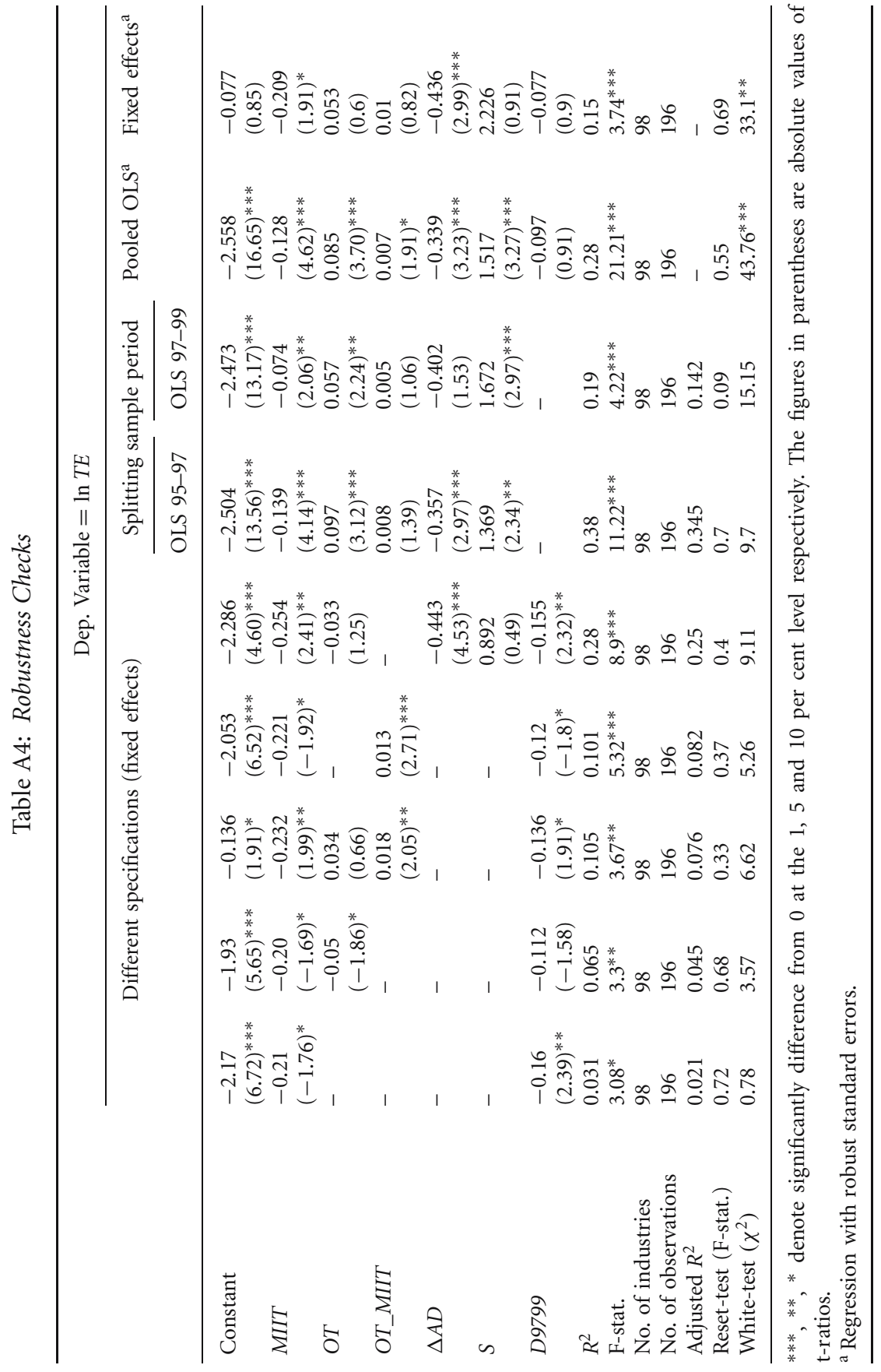


Table A5: Changes in Total Industry Employment and Marginal Intra-Industry Trade: Estimated Results

\begin{tabular}{|c|c|c|c|c|c|c|}
\hline \multirow[b]{3}{*}{ Constant } & \multicolumn{6}{|c|}{ Dependent variable $=\ln D E$} \\
\hline & \multicolumn{3}{|c|}{ Pooled OLS } & \multicolumn{3}{|c|}{ Fixed effects } \\
\hline & $\begin{array}{l}-2.94 \\
(16.51)^{* * *}\end{array}$ & $\begin{array}{l}-3.087 \\
(16.23)^{* * *}\end{array}$ & $\begin{array}{l}-3.426 \\
(12.47)^{* * *}\end{array}$ & $\begin{array}{l}-2.898 \\
(3.36)^{* * *}\end{array}$ & $\begin{array}{l}-3.048 \\
(3.27)^{* * *}\end{array}$ & $\begin{array}{l}-3.033 \\
(1.96)^{*}\end{array}$ \\
\hline MIIT & $\begin{array}{l}-0.132 \\
(3.51)^{* * *}\end{array}$ & $\begin{array}{l}-0.127 \\
(3.40)^{* * *}\end{array}$ & $\begin{array}{l}-0.171 \\
(3.51)^{* * *}\end{array}$ & $\begin{array}{l}-0.117 \\
(0.37)\end{array}$ & $\begin{array}{l}-0.123 \\
(0.38)\end{array}$ & $\begin{array}{l}-0.244 \\
(0.77)\end{array}$ \\
\hline OT & - & $\begin{array}{l}0.042 \\
(2.07)^{* *}\end{array}$ & $\begin{array}{l}0.095 \\
(2.41)^{* *}\end{array}$ & - & $\begin{array}{l}0.035 \\
(0.44)\end{array}$ & $\begin{array}{l}0.262 \\
(1.87)^{*}\end{array}$ \\
\hline OT_MIIT & - & - & $\begin{array}{l}0.01 \\
(1.42)\end{array}$ & - & - & $\begin{array}{l}0.042 \\
(1.73)^{*}\end{array}$ \\
\hline$\triangle A D$ & - & - & $\begin{array}{l}-0.485 \\
(2.20)^{* *}\end{array}$ & - & - & $\begin{array}{l}-0.373 \\
(1.28)\end{array}$ \\
\hline$S$ & - & - & $\begin{array}{l}0.921 \\
(1.14)\end{array}$ & - & - & $\begin{array}{l}-3.334 \\
(0.61)\end{array}$ \\
\hline D9799 & $\begin{array}{l}0.045 \\
(0.22)\end{array}$ & $\begin{array}{l}0.009 \\
(0.04)\end{array}$ & $\begin{array}{l}-0.032 \\
(0.16)\end{array}$ & $\begin{array}{l}0.046 \\
(0.26)\end{array}$ & $\begin{array}{l}0.015 \\
(0.08)\end{array}$ & $\begin{array}{l}-0.038 \\
(0.19)\end{array}$ \\
\hline$R^{2}$ & 0.06 & 0.081 & 0.12 & 0.001 & 0.003 & 0.08 \\
\hline F-stat. & $6.18^{* * *}$ & $5.63^{* * *}$ & $4.37^{* * *}$ & 0.13 & 0.16 & 1.67 \\
\hline No. of industries & 98 & 98 & 98 & 98 & 98 & 98 \\
\hline No. of observations & 196 & 196 & 196 & 196 & 196 & 196 \\
\hline Adjusted $R^{2}$ & 0.05 & 0.07 & 0.09 & -0.01 & -0.02 & 0.03 \\
\hline Reset-test (F-stat.) & 0.27 & 0.78 & 0.53 & 1.02 & $4.8^{* * *}$ & $2.33^{*}$ \\
\hline White-test $\left(\chi^{2}\right)$ & 1.59 & 6.05 & 15.64 & 0.14 & 1.35 & 7.12 \\
\hline
\end{tabular}

$* * *, * *, *$ denote significantly difference from 0 at the 1,5 and 10 per cent level respectively. The figures in parentheses are absolute values of t-ratios.

\section{References}

Balassa, B. (1966). Tariff Reduction and Trade in Manufactures among Industrial Countries. American Economic Review 56 (3): 466-473.

Bhagwati, J. (1998). Trade and Wages: A Malign Relationship? In S. Collins (ed.), Imports, Exports, and the American Worker. Washington, D.C.: Brookings Institution.

Brown, J., and J. Earle (2003). The Reallocation of Workers and Jobs in Russian Industry: New Evidence on Measures and Determinants. Economics of Transition 11 (2): 221-252.

Brülhart, M. (1994). Marginal Intra-Industry Trade: Measurement and Relevance for the Pattern of Industrial Adjustment. Weltwirtschaftliches Archiv/Review of World Economics 130 (4): 600-613.

Brülhart, M. (1999). Marginal Intra-Industry Trade and Trade-Induced Adjustment: A Survey. In M. Brülhart and R. Hine (eds.), Intra-Industry Trade and Adjustment: The European Experience. London: Macmillan. 
Brülhart, M. (2000). Dynamics of Intra-Industry Trade and Labour-Market Adjustments. Review of International Economics 8 (3): 420-435.

Brülhart, M. (2002). Marginal Intra-Industry Trade: Towards a Measure of NonDisruptive Trade Expansion. In P. Lloyd and H.-H. Lee (eds.), Frontiers of Research in Intra-Industry Trade. Basingstoke: Palgrave Macmillan.

Brülhart, M., and R. J. R. Elliott (1998). Adjustments to the European Single Market: Inferences from Intra-Industry Trade Patterns. Journal of Economic Studies 25 (3): 225-247.

Brülhart, M., and R. J. R. Elliott (2002). Labour-Market Effects of Intra-Industry Trade: Evidence for the United Kingdom. Weltwirtschaftliches Archiv/Review of World Economics 138 (2): 207-228.

Brülhart, M., A. Murphy, and E. Strobl (2004). Intra-Industry Trade and Job Turnover. Mimeo. University of Lausanne/University College Dublin/CORE, University of Louvain.

Brülhart, M., R. J. R. Elliott, and J. Lindley (2006). Intra-Industry Trade and Labour-Market Adjustment: A Reassessment Using Data on Individual Workers. Review of World Economics/Weltwirtschaftliches Archiv in this issue.

Cabral, M., R. E. Falvey, and C. R. Milner (2006). The Skill Content of Inter- and Intra-Industry Trade: Evidence for the United Kingdom. Review of World Economics/Weltwirtschaftliches Archiv in this issue.

Campos, N., and A. Dabusinskas (2002). So Many Rocket Scientists, So Few Marketing Clerks: Occupational Mobility in Times of Rapid Technological Change. CEPR Discussion Papers 3531. Centre for Economic Policy Research, London.

Davis, S., and J. Haltiwanger (1992). Gross Job Creation, Gross Job Destruction, and Employment Reallocation. Quarterly Journal of Economics 107 (3): 819863.

Davis, S., J. Haltiwanger, and S. Schuh (1996). Job Creation and Destruction. Cambridge: MIT Press.

Elliott, R. J. R., and J. Lindley (2006). Trade Skills and Adjustment Costs: A Study of Intra-Sectoral Labour Mobility. Review of Development Economics 10 (1): 20-41.

Falvey, R. E. (1981). Commercial Policy and Intra-Industry Trade. Journal of International Economics 11 (4): 495-511.

Falvey, R. E., and H. Kierzkowski (1987). Product Quality, Intra-Industry Trade and (Im)Perfect Competition. In H. Kierzkowski (eds.), Protection and Competition in International Trade. Oxford: Basil Blackwell.

Gabszewicz, J., and A. Turrini (2000). Worker's Skills and Industrial Equilibrium. International Journal of Industrial Organization 18 (4): 575-593.

Greenaway, D., and R. Hine (1991). Intra-Industry Specialization, Trade Expansion and Adjustment in the European Economic Space. Journal of Common Market Studies 29 (6): 603-622. 
Greenaway, D., and C. R. Milner (1986). Adjustment to Trade Expansion. In D. Greenaway and C. R. Milner, The Economics of Intra-Industry Trade. Oxford: Basil Blackwell.

Greenaway, D., R. Hine, and C. R. Milner (1994). Country-Specific Factors and the Pattern of Horizontal and Vertical Intra-Industry Trade in the UK. Weltwirtschaftliches Archiv/Review of World Economics 130 (1): 77-100.

Greenaway, D., R. Hine, and C. R. Milner (1995). Vertical and Horizontal IntraIndustry Trade: A Cross Industry Analysis for the United Kingdom. Economic Journal 105 (November): 1505-1518.

Greenaway, D., R. Upward, and P. Wright (1999). Sectoral Mobility in UK Labour Markets. GEP Research Paper 99/1. Centre for Research on Globalisation and Labour Markets, University of Nottingham.

Greenaway, D., R. Upward, and P. Wright (2000). Sectoral Transformation and Labour-Market Flows. Oxford Review of Economic Policy 16 (3): 57-75.

Greenaway, D., M. Haynes, and C. R. Milner (2002). Adjustment, Employment Characteristics and Intra-Industry Trade. Weltwirtschaftliches Archiv/Review of World Economics 138 (2): 256-276.

Haynes, M., R. Upward, and P. Wright (2002). Estimating the Wage Costs of Interand Intra-Sectoral Adjustment. Weltwirtschaftliches Archiv/Review of World Economics 138 (2): 229-253.

Helpman, E. (1981). International Trade in the Presence of Product Differentiation, Economies of Scale and Monopolistic Competition: A ChamberlinHeckscher-Ohlin Approach. Journal of International Economics 11 (3): 305340.

Helpman, E., and P. Krugman (1985). Market Structure and Foreign Trade. Cambridge, Mass.: MIT Press.

Hine, R., D. Greenaway, C. R. Milner, and R. J. R. Elliott (1994). Changes in Trade and Changes in Employment. An Examination of the Evidence from UK Manufacturing Industry 1979-87. SPES Research Paper, University of Nottingham.

Jacobson, L., R. Lalonde, and D. Sullivan (1993). Earnings Losses of Displaced Workers. American Economic Review 83 (4): 685-709.

Kletzer, L. (1998). Job Displacement. Journal of Economic Perspectives 12 (1): 115136.

Kol, J., and B. Kuijpers (1999). The Netherlands. In M. Brülhart and R. Hine (eds.), Intra-Industry Trade and Adjustment: The European Experience. London: Macmillan.

Krugman, P. (1981). Intra-Industry Specialization and the Gains from Trade. Journal of Political Economy 89 (5): 959-973.

Krugman, P. (1987). Economic Integration in Europe: Some Conceptual Issues. Reprinted in A. Jacquemin and A. Sapir (eds.), The European Internal Market. Oxford: Oxford University Press. 
Lovely, M., and D. Nelson (2000). Marginal Intraindustry Trade and Labor Adjustment. Review of International Economics 8 (3): 436-447.

Oliveras, J., and I. Terra (1997). Marginal Intra-Industry Trade Index: The Period and Aggregation Choice. Weltwirtschaftliches Archiv/Review of World Economics 133 (1): 170-179.

Porto, M., and F. Costa (1999). Portugal. In M. Brülhart and R. Hine (eds.), IntraIndustry Trade and Adjustment: The European Experience. London: Macmillan.

Rossini, G., and M. Burattoni (1999). Italy. In M. Brülhart and R. Hine (eds.), Intra-Industry Trade and Adjustment: The European Experience. London: Macmillan.

Sarris, A., P. Papadimitriou, and A. Mavrogiannis (1999). Greece. In M. Brülhart and R. Hine (eds.), Intra-Industry Trade and Adjustment: The European Experience. London: Macmillan.

Shin, K. (1997). Inter- and Intrasectoral Shocks: Effects on the Unemployment Rate. Journal of Labor Economics 15 (2): 376-401.

Smeets, H., and H. Reket (1999). Germany. In M. Brülhart and R. Hine (eds.), Intra-Industry Trade and Adjustment: The European Experience. London: Macmillan.

Tharakan, P. K., and M. Calfat (1999). Belgium. In M. Brülhart and R. Hine (eds.), Intra-Industry Trade and Adjustment: The European Experience. London: Macmillan.

Wacziarg, R., and J. Wallack (2004). Trade Liberalization and Intersectoral Labor Movements. Journal of International Economics 64 (2): 411-439. 